\title{
Review \\ Quantitative Epigenetics: A New Avenue for Crop Improvement
}

\author{
Vijay Gahlaut ${ }^{1, *} \mathbb{D}$, Gaurav Zinta ${ }^{1,2} \mathbb{D}$, Vandana Jaiswal ${ }^{1,2, *}$ and Sanjay Kumar ${ }^{1,2}$ \\ 1 Biotechnology Division, CSIR-Institute of Himalayan Bioresource Technology, Palampur, \\ Himachal Pradesh 176061, India; gzinta@gmail.com (G.Z.); sanjaykumar@ihbt.res.in (S.K.) \\ 2 Academy of Scientific and Innovative Research (AcSIR), CSIR-IHBT, Palampur, \\ Himachal Pradesh 176061, India \\ * Correspondence: vijaygahlaut@ihbt.res.in (V.G.); vandana@ihbt.res.in (V.J.)
}

Received: 14 September 2020; Accepted: 4 November 2020; Published: 7 November 2020

\begin{abstract}
Plant breeding conventionally depends on genetic variability available in a species to improve a particular trait in the crop. However, epigenetic diversity may provide an additional tier of variation. The recent advent of epigenome technologies has elucidated the role of epigenetic variation in shaping phenotype. Furthermore, the development of epigenetic recombinant inbred lines (epi-RILs) in model species such as Arabidopsis has enabled accurate genetic analysis of epigenetic variation. Subsequently, mapping of epigenetic quantitative trait loci (epiQTL) allowed association between epialleles and phenotypic traits. Likewise, epigenome-wide association study (EWAS) and epi-genotyping by sequencing (epi-GBS) have revolutionized the field of epigenetics research in plants. Thus, quantitative epigenetics provides ample opportunities to dissect the role of epigenetic variation in trait regulation, which can be eventually utilized in crop improvement programs. Moreover, locus-specific manipulation of DNA methylation by epigenome-editing tools such as clustered regularly interspaced short palindromic repeats/CRISPR-associated protein 9 (CRISPR/Cas9) can potentially facilitate epigenetic based molecular breeding of important crop plants.
\end{abstract}

Keywords: DNA methylation; epialleles; epiRILs; epigenetics; epigenome-wide association studies

\section{Introduction}

Epigenetic modifications modulate gene expression without any change in genomic DNA sequences that affects multiple aspects of plant growth and development [1]. These epigenetic modifications mainly involve DNA methylation, histone modification, and small RNA (sRNA)-mediated modifications [2]. Of these epigenetic modifications, DNA methylation is relatively well studied. In plants, DNA methylation predominantly occurs in the cytosines (C) of three sequence contexts: $\mathrm{CpG}, \mathrm{CpHpG}$, and $\mathrm{CpHpH}$, where $\mathrm{H}$ represents any base other than $\mathrm{G}$ (i.e., $\mathrm{A} / \mathrm{C} / \mathrm{T}$ ). DNA methylation at each sequence context is regulated by a particular set of enzymes named cytosine-5 DNA methyltransferases (C5-MTases) having complementary 'de novo' and 'maintenance' methylation activities [3,4]. In the de novo methylation process, unmethylated cytosine residues are methylated, while in methylation maintenance the preexisting methylation patterns are maintained after DNA replication [5]. Different C5-MTases including Domains Rearranged Methylases (DRMs), Methyltransferases (METs), and Chromomethylases (CMTs) participate in these processes. The DRMs are involved in de novo DNA methylation via RNA-directed DNA methylation (RdDM) in all three DNA sequence contexts [6]. The DRM2, an ortholog of mammalian DNMT3, is involved in CpHpH methylation of euchromatic regions [7]. The METs are involved in the maintenance of $\mathrm{CpG}$ methylation during DNA replication [8]. The CMTs are involved in the maintenance of $\mathrm{CpHpG}$ and $\mathrm{CpHpH}$ methylations. In Arabidopsis thaliana (L.) Heynh (Arabidopsis), CMT2 catalyzes $\mathrm{CpHpH}$ methylation, 
while $\mathrm{CpHpG}$ methylation is catalyzed by CMT3 and to a lesser extent by CMT2 [9,10]. The roles of DNA methylation in plant development and responses to environmental stress conditions have been discussed in detail previously [11].

The recent advances in bisulphite sequencing (BS-Seq) and methylC-sequencing (MethylC-seq) allow profiling of DNA methylation status across entire genomes within a species $[8,12]$. Also, species-level epigenomic diversity in the natural populations of Arabidopsis collected from diverse locations of the globe has been determined [13]. Whole-genome bisulfite sequencing (WGBS) is particularly powerful as it constructs the genomic maps of DNA methylation at a single-base resolution level [14]. WGBS has been utilized in the methylome analysis of several plant species including model plants Arabidopsis and crop plants Zea mays and Triticum aestivum [15-17]. WGBS analysis in Arabidopsis has shown that $5.26 \%$ of all genomic $\mathrm{C}$ bases are methylated and their allocation on the genome was uneven, for instance, about $24 \%$ of $\mathrm{CpG}$ context was found to be methylated, which is followed by $\mathrm{CpHpG}(6.70 \%)$, and $\mathrm{CpHpH}(1.70 \%)$ contexts $[15,18]$. However, substantial variation in methylation patterns has been observed between plant species (see Table 1). For instance, CpG context methylation ranged from $24 \%$ (Arabidopsis) to $93 \%$ (Cicer arietinum), $\mathrm{CpHpG}$ methylation varied from $3.48 \%$ (Triticum aestivum) to $89 \%$ (Cicer arietinum), and $\mathrm{CpHpH}$ methylation ranged from $1.36 \%$ (Eucalyptus grandis) to 38\% (Cicer arietinum). The CpG methylation is more prevalent and makes the largest portion of total DNA methylation in plants. Many factors determine the observed variation in methylation levels in different contexts, which include genome size, architecture, and distinction in the activity of methylation targeting pathways.

Table 1. Genome size, total number of repeat elements, DNA methylation levels at three sequence contexts ( $\mathrm{CpG}, \mathrm{CpHpG}$, and $\mathrm{CpHpH})$ in different plant species, where methylation \% indicates per-site methylation

\begin{tabular}{|c|c|c|c|c|c|c|c|c|}
\hline $\begin{array}{c}\text { Species } \\
\text { (Common Name) }\end{array}$ & Family & Monocot/Eudicot & $\begin{array}{l}\text { Genome } \\
\text { Size }(\mathrm{Mb})\end{array}$ & $\begin{array}{c}\text { Repeat } \\
\text { Elements }\end{array}$ & CpG (\%) & CpHpG (\%) & $\mathrm{CpHpH} \mathrm{( \% )}$ & Reference \\
\hline Arabidopsis thaliana (Arabidopsis) & Brassicaceae & Eudicot & 135 & 31,189 & 24.00 & 6.70 & 1.70 & [15] \\
\hline Beta vulgaris (beet) & Amaranthaaceae & Eudicot & 758 & 656,014 & 92.00 & 81.00 & 18.80 & [4] \\
\hline Brassica oleracea (cabbage) & Brassicaceae & Eudicot & 648 & 532,987 & 52.50 & 22.00 & 5.11 & [4] \\
\hline Brassica rapa (mustard) & Brassicaceae & Eudicot & 485 & 218,781 & 37.20 & 17.28 & 4.44 & [4] \\
\hline Cajanus cajan (pigeonpea) & Fabaceae & Eudicot & 833 & $1,127,729$ & 70.23 & 54.60 & 9.87 & [19] \\
\hline Camellia sinensis (tea) & Theaceae & Eudicot & 3100 & $5,164,785$ & 82.00 & 70.00 & 10.00 & [20] \\
\hline Cannabis sativa (canabis) & Cannabaceae & Eudicot & 818 & 376,401 & 75.50 & 65.00 & 8.72 & [4] \\
\hline $\begin{array}{l}\text { Capsella rubella (pink } \\
\text { shepherd's purse) }\end{array}$ & Brassicaceae & Eudicot & 219 & 39,716 & 32.00 & 9.90 & 34.70 & [4] \\
\hline Cicer arietinum (chickpea) & Fabaceae & Eudicot & 738 & 853,514 & 93.00 & 89.00 & 38.00 & [21] \\
\hline Citrus clementina (clementine) & Rutaceae & Eudicot & 370 & 205,699 & 45.83 & 25.13 & 8.26 & [4] \\
\hline Cucumis sativus (cucumber) & Cucurbitaceae & Eudicot & 367 & 57,750 & 45.88 & 16.50 & 4.12 & [4] \\
\hline Eucalyptus grandis (rose gum) & Myrtaceae & Eudicot & 640 & 689,306 & 37.12 & 19.96 & 1.36 & [4] \\
\hline Fragaria vesca (strawberry) & Rosaceae & Eudicot & 240 & 129,500 & 48.35 & 20.63 & 2.32 & [4] \\
\hline Glycine max (soybean) & Fabaceae & Eudicot & 1115 & 38,581 & 63.20 & 38.40 & 4.10 & [22] \\
\hline Gossypium raimondii (cotton) & Malvaceae & Eudicot & 880 & 489,564 & 71.97 & 57.80 & 13.14 & [4] \\
\hline Lotus japonicus (birdsfoot trefoil) & Fabaceae & Eudicot & 472 & 160,505 & 67.75 & 36.59 & 8.66 & [4] \\
\hline Malus domestica (apple) & Rosaceae & Eudicot & 742 & $1,245,768$ & 63.50 & 44.14 & 4.57 & [4] \\
\hline Manihot esculenta (cassava) & Euphorbiaceae & Eudicot & 742 & 258,416 & 51.53 & 30.38 & 1.90 & [4] \\
\hline Medicago truncatula (barrel clover) & Fabaceae & Eudicot & 465 & 375,003 & 59.80 & 16.94 & 5.09 & [4] \\
\hline Populus trichocarpa (poplar) & Salicaceae & Eudicot & 500 & 173,230 & 43.95 & 26.78 & 5.01 & [4] \\
\hline Prunus persica (peach) & Rosaceae & Eudicot & 265 & 95,678 & 50.18 & 19.59 & 3.64 & [4] \\
\hline Ricinus communis (castor bean) & Euphorbiaceae & Eudicot & 323 & 575,449 & 64.54 & 37.94 & 11.97 & [4] \\
\hline Solanaceae lycopersicum (tomato) & Solanaceae & Eudicot & 907 & 887,009 & 84.05 & 54.84 & 8.35 & [4] \\
\hline Solanaceae tuberosum (potato) & Solanaceae & Eudicot & 840 & 404,861 & 70.90 & 42.20 & 15.80 & [23] \\
\hline Vitis vinifera (grape vine) & Vitaceae & Eudicot & 487 & 449,466 & 45.95 & 20.43 & 1.15 & [4] \\
\hline
\end{tabular}


Table 1. Cont.

\begin{tabular}{ccccccccc}
\hline $\begin{array}{c}\text { Species } \\
\text { (Common Name) }\end{array}$ & Family & Monocot/Eudicot & $\begin{array}{c}\text { Genome } \\
\text { Size (Mb) }\end{array}$ & $\begin{array}{c}\text { Repeat } \\
\text { Elements }\end{array}$ & CpG (\%) & CpHpG (\%) & CpHpH (\%) & Reference \\
\hline $\begin{array}{c}\text { Brachypodium distachyon } \\
\text { (stiff brome) }\end{array}$ & Poaceae & Monocot & 352 & 51,793 & 49.17 & 19.17 & 1.41 & {$[4]$} \\
\hline Oryza sativa (rice) & Poaceae & Monocot & 430 & 447,163 & 54.70 & 37.30 & 12.00 & {$[16]$} \\
\hline Panicum hallii (Hall's panicgrass) & Poaceae & Monocot & 550 & 154,970 & 56.28 & 29.97 & 2.43 & {$[4]$} \\
\hline Panicum virgatum (switchgrass) & Poaceae & Monocot & 1600 & $1,793,620$ & 53.56 & 35.74 & 3.06 & {$[4]$} \\
\hline Setaria viridis (green foxtail) & Poaceae & Monocot & 515 & 372,068 & 44.49 & 23.25 & 1.56 & {$[4]$} \\
\hline Sorghum bicolor (sorghum) & Poaceae & Monocot & 730 & 397,003 & 84.75 & 73.25 & 5.81 & {$[4]$} \\
\hline Triticum aestivum (wheat) & Poaceae & Monocot & 17,000 & $3,968,974$ & 53.30 & 3.48 & 1.41 & {$[17]$} \\
\hline Zea mays (maize) & Poaceae & Monocot & 2665 & $1,971,471$ & 86.00 & 74.00 & 5.40 & {$[7]$} \\
\hline
\end{tabular}

DNA methylation together with histone modifications and non-histone proteins delineates chromatin structure and its accessibility to transcriptional machinery. Thus, it plays an important role in gene expression regulation, transposon element (TE) silencing, and trait inheritance [24]. In plants, DNA methylation levels are generally higher at TEs as compared to genic regions. Silencing TEs is required to maintain genome stability, and it is mediated via RdDM [25]. In spite of having a crucial role in distinct biological processes, the application of DNA methylation in crop improvement remains to be fully explored. The epialleles (epigenetic alleles) are loci that differ in chromatin states and get transmitted to the next generations [26-28]. Epialleles provide an additional source of variation, which are involved in the regulation of phenotypic diversity. Various stable epialleles affecting floral morphology [29], flowering time [30], disease resistance [31], pigmentation [32], and leaf senescence [33] have been reported in different plant species. In Arabidopsis, epigenetic recombinant inbred lines (epiRILs) have been developed, which show variation and high heritability for traits like flowering time and plant height as well as stable inheritance of DNA methylation variants [34]. Utilizing this epiRIL population, epigenetic quantitative trait loci (epiQTL) controlling flowering time and primary root length were identified that showed high heritability (up to 90\%) [35]. Considering that some epiQTLs are stably inherited and show phenotypic diversity, they are good targets for natural/artificial selection for crop improvement.

In this review, we first discuss various epialleles controlling phenotypic traits in plants. Second, the development of epiRILs and epiQTL mapping populations in Arabidopsis and other important crop plants are described, which can be used for quantitative epigenetic studies to identify epigenetic variants controlling trait. Finally, locus-specific manipulation of DNA methylation levels by using site-specific nucleases to generate epialleles is highlighted, which can be utilized for crop trait improvement.

\section{Epialleles (Natural and Mutagen Induced)}

Although a number of genes/QTLs have been identified in various plants, however, missing heritability is still a major challenge for researchers and breeders where unknown components regulate phenotype in addition to genes/QTLs. Epigenetic modifications could be one of the major causes of missing heritability [36]. Changes in the DNA methylation status of a particular gene may affect its expression and can be trans-generationally inherited, which leads to trait variation [37]. Such stably inherited epigenetic variants are referred to as epialleles that contribute to phenotypic variation in plants.

Several epialleles have been reported in the model plant Arabidopsis and crop plants like rice, maize, field mustard (details are given in Table 2). The first classical example of epiallele was reported in Arabidopsis and known as clark-kent (clk). It is a natural epimutant with an enhanced number of stamens and carpels. In this epimutant, hypermethylation of cytosine occurred at flower development locus SUPERMAN [29]; while hypomethylation of this locus in clk mutants was found unstable and reverted to the wild type phenotype. A total of seven independent $c l k$ mutants were reported with similar phenotypes. Peloric mutant is another classical example of epialleles found in toadflax (Linaria vulgaris). Peloric mutants (radial flower) showed different flower symmetry as compared 
to wild type plants (bilateral flower). In this epimutant, hypermethylation occurs at the promoter of Lcyc gene (homolog of CYCLOIDEA gene of Antirrhinum, responsible for floral symmetry) and led to the silencing of the gene. This epimutation is stably inherited across the generation over 100 years; however, loss of hypermethylation of the promoter of the Lcyc gene may regain bilateral floral symmetry of wild type [38]. In tomato, two epialleles were reported that affect fruit ripening and vitamin E accumulation. Hypermethylation at the promoter of colorless non-ripening (cnr) locus encoding SBP-box transcription factor (TF) causes ripening defective fruits in tomato [39]. Similarly, DNA methylation of Vitamin E (VTE3) gene promotor affects its expression that leads to vitamin $\mathrm{E}$ accumulation in tomato fruits [40]. In melon, it was shown that DNA hypermethylation in the promoter of CmWIP1 (WASP/N-WASP-interacting protein 1) TF causes the transition from male to female flowers [41]. In the case of rice, six epialleles were reported that affect phenotypes such as dwarf stature, panicle architecture, leaf angle, seed size, and photosynthetic capacity (Table 2). In Brassica, the epiallele $S$ locus protein 11/S locus (SP11/SCR locus) was involved in the dominance effect that regulates the self-incompatibility [42].

Table 2. List of some stable epialleles reported in different plant species

\begin{tabular}{|c|c|c|c|c|}
\hline Species & Gene/Locus & Epigenetic Variation & Phenotypic Traits & References \\
\hline \multirow{7}{*}{ Arabidopsis thaliana } & SUP (SUPERMAN) & Mutagen induced & $\begin{array}{l}\text { Increased numbers of } \\
\text { stamens and carpels }\end{array}$ & [29] \\
\hline & $\begin{array}{c}\text { PAI2 (Phosphoribosyl } \\
\text { Anthranilate Isomerise) }\end{array}$ & Trans-acting (small RNAs) & $\begin{array}{l}\text { Only gene expression } \\
\text { affected; no specific } \\
\text { phenotype }\end{array}$ & [43] \\
\hline & $B A L 1$ & Mutagen induced & $\begin{array}{l}\text { Dwarfing and elevated } \\
\text { disease resistance }\end{array}$ & [31] \\
\hline & AG (AGAMOUS) & Mutagen induced & Affect flower structure & [44] \\
\hline & BNS (BONSAI) & $d d m 1$-induced syndrome & Stunted growth & [45] \\
\hline & FOLT1(folate transporter 1 ) & Trans-acting (small RNAs) & Reduced fertility & [46] \\
\hline & $\begin{array}{c}\text { HISN6B } \\
\text { (Histidinol-phosphate } \\
\text { aminotransferase 1) }\end{array}$ & Spontaneous & Hybrid incompatibility & [48] \\
\hline \multirow{5}{*}{ Zea Mays } & $r 1(\operatorname{red} 1)$ & Spontaneous & Reduced pigmentation & [49] \\
\hline & $b 1$ (booster 1$)$ & Spontaneous & Reduced pigmentation & [50] \\
\hline & pl1 (purple plant 1 ) & Spontaneous & Reduced pigmentation & [51] \\
\hline & $p 1$ (pericarp color 1$)$ & Spontaneous & Reduced pigmentation & [32] \\
\hline & lpa1(low phytic acid1) & Paramutagenic & $\begin{array}{l}\text { High inorganic phosphate } \\
\text { in seeds }\end{array}$ & [52] \\
\hline
\end{tabular}


Table 2. Cont.

\begin{tabular}{|c|c|c|c|c|}
\hline Species & Gene/Locus & Epigenetic Variation & Phenotypic Traits & References \\
\hline \multirow{5}{*}{ Oryza sativa } & D1 (Drawf1) & Spontaneous & Dwarf & [53] \\
\hline & $\begin{array}{l}\text { SPL14 (Squamosa } \\
\text { Promoter binding } \\
\text { protein-Like) }\end{array}$ & Spontaneous & $\begin{array}{l}\text { Panicle branching } \\
\text { and higher grain } \\
\text { yield }\end{array}$ & [54] \\
\hline & $\begin{array}{c}\text { FIE1 } \\
\text { (Fertilization-Independent } \\
\text { Endosperm 1) }\end{array}$ & Spontaneous & Dwarf & [55] \\
\hline & $\begin{array}{c}\text { RAV6 [Related to Abscisic } \\
\text { Acid Insensitive } 3 \\
\text { (ABI3)/Viviparous1 (VP1) 6] }\end{array}$ & Spontaneous & $\begin{array}{l}\text { Larger lamina inclination } \\
\text { and smaller grain size }\end{array}$ & [56] \\
\hline & AK1 (Adenylate Kinase 1) & Spontaneous & $\begin{array}{l}\text { Defects in photosynthetic } \\
\text { capacity }\end{array}$ & [57] \\
\hline Cucumis melo & $\begin{array}{c}\text { CmWIP1 } \\
(\text { WASP/N-WASP-interacting } \\
\text { protein } 1)\end{array}$ & Transposon Insertion & Sex determination & [41] \\
\hline
\end{tabular}

Another important epigenetic phenomenon is known as paramutation. It was initially observed in the $r 1$ (red1) locus that regulates anthocyanin pigment biosynthetic pathway in maize [49], and subsequently found in booster 1 (b1), purple plant1 ( $p l 1)$, and pericarp color1 ( $p 1$ ) loci, which also regulate anthocyanin pigment biosynthetic pathway [32,50,51], and low phytic acid1 (lpa1-241) that was involved in phytic acid biosynthesis [52]. Besides spontaneous mutations, small interfering RNA (siRNA) also plays a vital role in the development of epialleles in plants. In Arabidopsis, silencing of the folate transporter 1 (AtFOLT1) gene is regulated by siRNAs derived from the truncated copies of AtFOLT2 locus, which causes reduced fertility [46]. Furthermore, methylation of transposable elements is also found to affect the phenotype substantially. For instance, hypomethylation of intronic TE (Karma retro TE) caused abnormal splicing of DEFICIENS (DEF) gene, resulting in parthenocarpy and reduced yield in oil palm [59]. Moreover, epialleles are well known to control manytraits including flower/fruit-related traits, sex determination, plant architecture and vitamin accumulation in different plant species (see Table 2). Epialleles also regulate the homeostasis between euchromatin and heterochromatin to maintain genome stability, as the loss of heterochromatin would expose genes to DNA methylation machinery. It was recently, shown that DNA methylation is inversely correlated to heterochromatin in Arabidopsis [60].

\section{Epigenetic Recombinant Inbred Lines (epiRILs)}

EpiRILs are referred to as the recombinant inbred lines that differ for DNA methylation patterns and show no genetic variation. EpiRILs represent an excellent resource to identify the effect of DNA-methylation on phenotypes [34]. Under changing climatic conditions, epigenetic modifications could play a crucial role in plant adaptation to environmental stresses [61]. epiRILs developed in Arabidopsis have been used to explore the effect of environmental factors, which revealed that stress-induced epigenetic modifications could be heritable and provide phenotypic plasticity to plants to endure stress [62].

In Arabidopsis, at least two different epi-RIL populations have been developed [34,63]. One epi-RIL population was derived from the crossing of met1 mutant and its isogenic wild type [63]. The met1 mutant is defective in DNA methyltransferase $[8,64]$. In the $\mathrm{F}_{2}$ and subsequent generations, only wild type MET1 alleles were selected in order to prevent de novo DNA methylations. In each generation, progenies were advanced using the single seed descent method. Similarly, another epi-RIL population was derived from the crossing of $d d m$ mutant and its isogenic wild type [34]. The $d d m$ mutant 
is defective in the DDM locus that encodes nucleosome-remodeling ATPase required to maintain $C$ methylation $[65,66]$. Due to the utilization of isogenic lines in crossing, these epiRILs have no genetic variations; however, epigenetic variations are maximum. Schematic representation of the development of epiRILs is given in Figure 1. The following points need to be considered while studying transgenerational epigenetic variations.

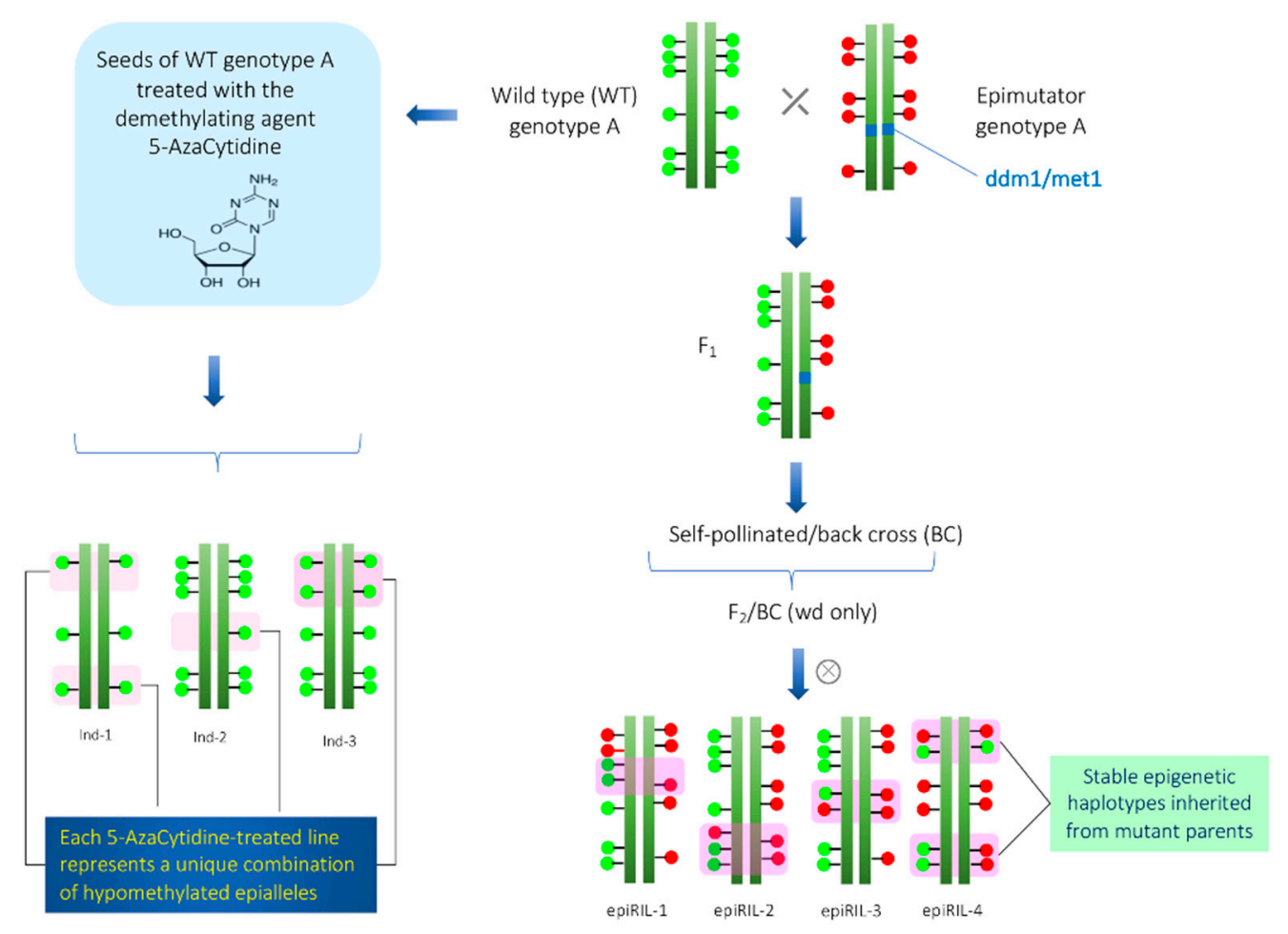

Figure 1. Construction of epiRILs (hypomethylated population) for quantitative epigenetics. In the left side, the scheme for the construction of hypomethylated population using demethylating agent 5-AzaCytidine is shown. On the right side, scheme for construction of epiRILs with stable inheritance by crossing of two parents (wild-type and epimutator parents (met1 or $d d m 1$ )) with different epigenetic states is shown. The green and red circles that overlay the genome sequence illustrates the different epigenetic states of the two parents.

\subsection{Persistence of Epigenetic Modification in the epiRILs}

Epigenetic modifications are heritable and maintained across several generations as revealed from epiRILs developed by the crossing of mutants (met1 or $d d m 1$ ) with its isogenic wild types $[67,68]$. In the $d d m$ epiRILs, epigenetic loci targeted by small RNAs were extensively remethylated, while nontargeted loci remained unmethylated [69]. In contrast, Flowering Wageningen (FWA) epiallele associated with flowering time became methylated in the subsequent generations despite being targeted by small RNA $[34,63]$. The mechanism underlying remethylation process and the role of small RNAs in remethylation remain unclear. However, a recent study provides mechanistic insights on the formation and transmission of epialleles and suggested that histone and DNA methylation marks are critical in determining the ability of RdDM target loci to form stable epialleles [70]. High levels of active histone mark H3K4me3 at specific loci prevent recruitment of the RdDM machinery, whereas high levels of H3K18ac enable ROS1 (Repressor of Silencing 1) to access specific loci, therefore antagonizing RdDM-mediated re-establishment of DNA methylation. 


\subsection{Phenotypic Variation and Stability in the epiRILs}

Continuous variations for different traits observed in the abovementioned two epi-RILs suggested that epigenetic modification was involved in the regulation of polygenic traits also. Although two epi-RILs differed for different traits. For instance, epiRILs derived from met1 mutant showed variation for biotic (bacterial pathogen) and abiotic stress (salt) tolerance [63]; however, in the case of epiRILs derived from $d d m 1$ mutant, variation can be clearly seen for morphological traits like flowering time and plant height [34].

The stability of phenotypic characters in the above two epiRILs is quite different. Phenotypes in met 1 derived epiRILs are very unstable, and several lines were unable to advance to $\mathrm{F}_{8}$ generation due to abnormal development and infertility [63]. Unlike, $d d m 1$ derived epiRILs were found highly stable and more than $99 \%$ lines advanced to F8 generations without any abnormality [34].

To explain phenotypic instability, Reinder et al. [63] studied the methylation pattern in met1-derived epiRILs. They found that some cytosine methylation sites were highly segregating even in $\mathrm{F}_{8} / \mathrm{F}_{9}$ generations and suggested that some methylations sites are very unstable and cannot be fixed by repeated selfing. Furthermore, several ectopic and hypomethylations were observed that were different from any of the parental genotypes, suggesting de-novo methylations may be a possible reason for the phenotypic and epigenetic instability across generations in met1 derived epiRILs [63]. In contrast, in $d d m 1$-derived epiRILs, cytosine remethylation seems to be the reason for nonparental cytosine methylation [69].

\subsection{Epigenetic Basis of Heterosis}

Heterosis is a phenomenon where $\mathrm{F}_{1}$ hybrid shows enhanced phenotypes than their respective parents. Heterosis has extensively been exploited as a potential breeding strategy for crop improvement. The importance of heterosis, its application in plant breeding, and molecular mechanisms underlying heterosis have been discussed elsewhere [71-74]. Many genetic factors contribute to the heterotic phenotype; however, epigenetic interactions between two parental alleles also play a critical role in heterosis $[75,76]$. Hybrids of Arabidopsis derived from two genetically similar but epigenetically diverse ecotypes C24 and Ler showed more than 250\% enhanced biomass over parents advocated the importance of epigenetics in heterosis [77]. Out of three different cytosine methylation contexts, the highest alteration was observed at $\mathrm{CpG}$ site; however, $\mathrm{CpHpH}$ and $\mathrm{CpHpG}$ methylations slightly increased in hybrids than parental genotypes [75]. Furthermore, $75 \%$ methylation changes were observed in TEs, and more than 95\% methylation increase was observed in siRNA generating regions [75]. In Arabidopsis, hybrids derived from Col-wt (female parent) and 19 epiRILs (male parents) showed positive and negative heterosis for six growth-related traits. DNA methylation profiling of hybrids and parents identified epiQTLs associated with heterosis and suggested that DMRs present in the parental genotypes are responsible for heterosis [74]. The above results provide evidence that epigenetic components act as critical determinants of heterosis, which can be exploited for crop improvement.

\section{Development of Epigenetically Modified Population by Chemical Agents}

The generation of epigenetic mutants like met 1 or $d d m 1$ is still not very common in non-model plants. Therefore, chemical agents can be used to induce epigenetic modifications that may serve the purpose to study the effect of epigenetics on quantitative traits. Several chemical compounds are known to induce epigenetic modifications-including DNA methylation, histone modification, etc.-with different modes of action [78]. For instance, chemicals like 5-Azacytidine (5-AzaC), 5-Aza 2'deoxycytidine, and Zebularine inhibit the methyltransferase activity and lead to the reduction of transfers the methyl group from S-adenosylmethionine (SAM) to the cytosine ring. Mutagenesis with these chemicals would lead to the development of hypomethylated population. On the other hand, some chemicals act as histone deacetylase inhibitors and increase the histone acetylation and 
reactivate the silent genes. Chemicals like trichostatin-A (TSA), Helminthosporium carbonum (HC) toxin, nicotinamide, diallyl disulfide sodium butyrate etc. are good examples of histone deacetylase inhibitors. Besides these, some chemicals-like sulfamethazine (SMZ), ethionine, and dihydroxypropyl adenine (DHPA) - hamper the supply of methyl groups. These chemicals decrease the folate pool and cause methyl deficiency.

The availability of a wide range of chemical mutagens would be a great asset to create epigenetically modified populations in plants. A successful example of the adoption of chemical methods to develop a hypomethylated population in Brassica, where epialleles were developed by using 5-AzaC, and this hypomethylated population showed variability for different phenotypic traits [79].

Transgenerational inheritance of some phenotypes has also been demonstrated. When compared to untreated controls, BraRoAZ population (hypomethylated population of B. rapa line R-o-18) showed a decrease immuno-staining of $5 \mathrm{mC}$ on pachytene chromosomes. Furthermore, methylation sensitive amplified polymorphism (MSAP) showed high divergence as well as variability. High phenotypic variability was also observed for different seed related characters like yield, protein content, oil content, erucic acid, linoleic acid, and palmitic acid. Each line in the BraRoAZ population represented a unique combination of hypomethylated epialleles. Thus, efforts should be made for the development of epigenetically modified populations using chemical agents in other crops.

\section{Development of User-Friendly Epigenetic Markers}

Epigenetic markers are important to study quantitative epigenetics and identify epialleles associated with traits of interest. Several epigenetic markers have been identified to be involved in biological and molecular functions in plants [36,80-82]. However, utilization of these methylation marks into crop breeding programs is still lacking. Developing a cost-effective and easy genotyping platform for identifying and selecting desirable epiallele is needed in crop plants. For the identification of epialleles, three major approaches are available and widely used in the case of human (i) bi-sulfite sequencing PCR (BSP), (ii) methylation-specific PCR (MSP), and (iii) chop-PCR [83,84]. The first two approaches require bi-sulfite conversion of non-methylated cytosine to uracil. Bisulfite conversion is a very important and crucial step in these methods. Classical bisulfite conversion approaches involve lots of effort and time, even though conversion efficiency and yield are less. With advancement in technologies, now commercial kits are available with high yield and more than $99 \%$ conversion efficiency [85]. These kits also facilitate the rapid conversion within 3-4 h. An exhaustive comparison of different commercially available kits for bisulfite conversion efficiency and cost-effectiveness has been published elsewhere [86]. In BSP, after bisulfite conversion, the targeted region is PCR amplified and then sequenced to identify the epialleles. However, in MSP, sequencing is not required, and the targeted region is amplified with methylation-specific primer pairs to distinguish epialleles. In chop-PCR, genomic DNA is partially digested with methylation-sensitive restriction enzymes (MSREs) followed by PCR amplification of the targeted region. Furthermore, quantitative measurement of DNA methylation can be done through MethylLight and methylation-sensitive high-resolution melting (MS-HRM).

Although the development and utilization of epigenetic markers are very much successful in humans [87], however, this area of research lags behind in the case of plants. Therefore, there is an urgent need to develop online platforms and databases to assess $f$ of epigenetic markers with full description.

\section{Quantitative Epigenetic Models for Complex Trait}

Several statistical methods exist to detect epigenetic variations and their impact on the phenotype or epiQTLs [36,80-82]. The significance and accuracy of epiQTLs identification are affected by several factors like recombination, transgressive segregation, instability of epialleles, and parent off origin effect. These factors may create confounding effects during epiQTLs analysis and result in false positives or false negatives. To deal with these interrupting factors, Johannes and Colome-Tatche [81] suggested that population derived from crossing between isogenic lines (dissimilar for epigenetic marks) are 
the most suitable material. Tal et al. [80] derived covariances between kinship due to epigenetic transmissibility and environmental effect. They modeled the number of chances for epigenetic reset between generations and environmental induction, and estimated the heritable epigenetic variance and epigenetic transmissibility. Furthermore, multiple testing is the major drawback of quantitative genetics because it can give several false positives. Jaffe et al. [88] developed a statistical model to deal with multiple testing corrections during genome-wide identification of epigenetic variability. These models can be useful to study the missing heritability contributed by epigenetic variation [81,89], but did not consider the phenotypic variation contributed by epigenetic variation. Wang et al. [90] suggested a model to estimate phenotypic variation explained by epigenetic variation and their effects on phenotypic values and also the interaction of epigenetic and genetic effects (additive and dominant). This model also predicts the proportion of genetic variation contributed by epigenetic modifications.

\section{EpiQTLs and Epigenome-Wide Association Study (EWAS)}

As discussed, epigenetic markers are stably inherited across generations and are randomly present in the genome with high frequency. These features allow the exploitation of epigenetic markers in the identification of epiQTLs. Unlike QTLs, epiQTLs are epigenomic loci where no polymorphism for the DNA nucleotide sequence occurs but they differ for cytosine methylation levels, and these differential methylation patterns regulate phenotypic variation of quantitative traits. In Arabidopsis, Cortijo et al. [35] identified major epiQTLs explaining 60-90\% heritability for quantitative traits like root length and flowering time using $d d m 1$-derived epi-RILs. These epiQTLs were found reproducible and useful for artificial selection. Furthermore, 99.9\% epialleles were found stable; and based on the inheritance and recombination events epigenotype map (E-map) was constructed using mutagenic accumulation lines [26]. Another study in Brassica identified epiQTLs for seven agronomic traits using methylation-sensitive amplified fragment length polymorphism (MS-AFLP) and retrotransposon epimarkers [91]. High stability of epigenetic marks was found at different developmental stages, environmental conditions and transgenerational levels. In Sorghum, by implementing MSAP genotyping approach, 122 methylation polymorphic loci were generated to construct E-map, which harbored methylation hotspots [92]. In soybean, co-segregation of differentially methylated regions (DMRs) in RILs allowed the identification of methylQTL (QTLs associated with DNA methylation) [93]. Thus, the stable inheritance of epialleles across generations makes it a potential regulator of phenotypic variations in crops where genetic variation is negligible [26].

Like genome-wide association studies (GWAS), epigenome-wide association study (EWAS) may prove a worthwhile approach to explore the impact of the epigenetic modifications on phenotype where genome-wide epimarkers are available (Figure 2). EWAS is based on linkage disequilibrium (LD) mapping, which utilizes natural populations and historic recombination events and can thus accomplish high-resolution mapping. A number of EWAS studies have been conducted in humans, which identified that epigenetic modifications are associated with several human diseases like Parkinson's disease [94], coronary artery disease [95], Alzheimer's disease [96], and Type 2 diabetes [97]. Moreover, to gather the extensive knowledge generated through EWAS in humans, EWAS Atlas has also been developed [98]. However, there is a limited number of EWAS performed in plants, and so far, a single EWAS study identified epigenetic modification associated with a mantled abnormality in oil palm [59]. By using somatic clones (diverse for mantled abnormality and oil yield), a locus MANTLED was identified where hypomethylation in LINE retrotransposon leads the alternate splicing and premature termination. 

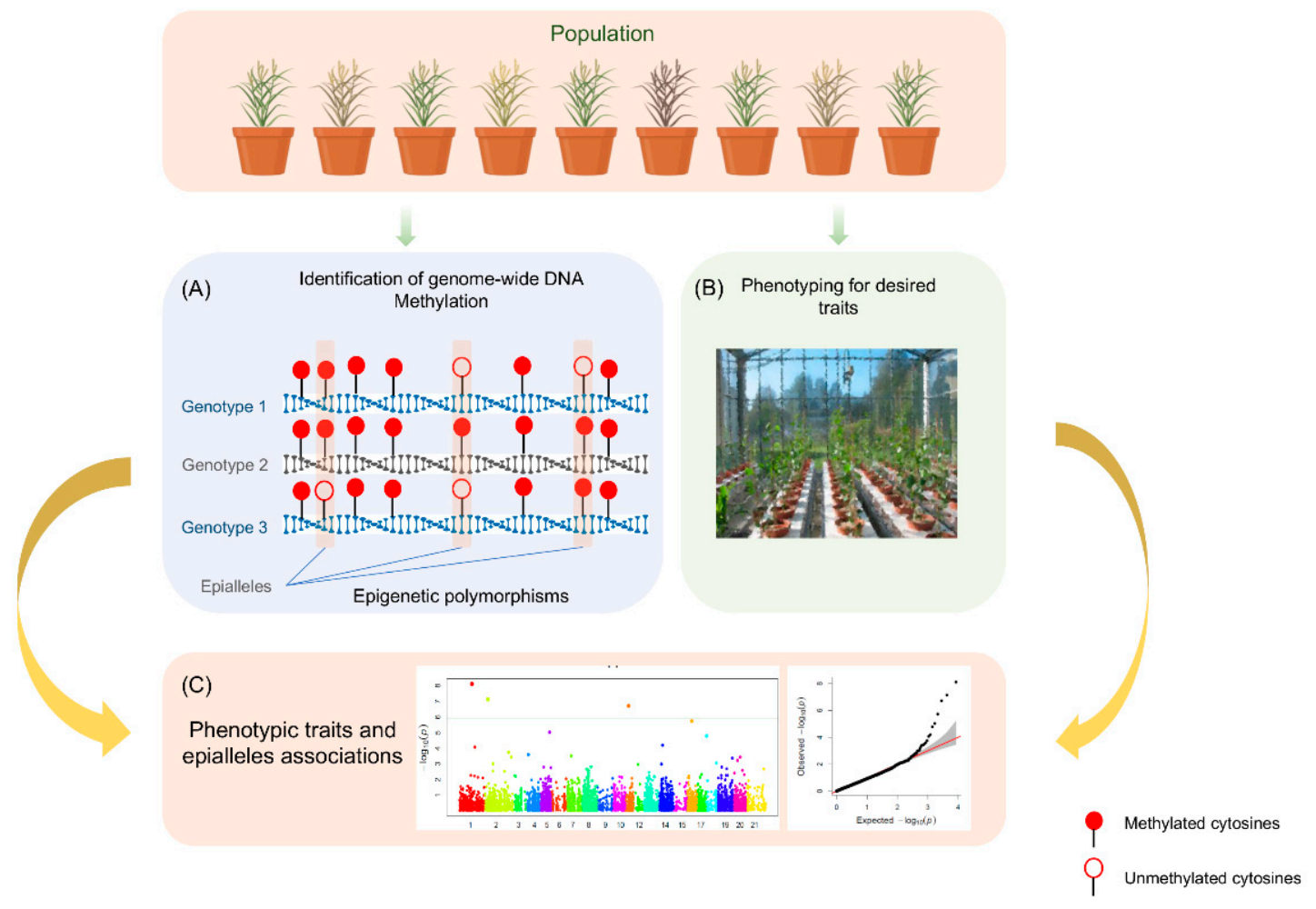

Figure 2. Schematic representation of epigenome-wide association mapping (EWAS) involving three major steps: (A) epigenotyping to explore different epialleles, (B) precise phenotyping of diverse germplasm, (C) statistical analysis to identify EpiQTLs.

Linkage mapping and LD mapping have their own importance and limitations. To overcome limitations, integrated genetic mapping by combining linkage and linkage-disequilibrium is recommended. Recently, an integrated linkage and linkage-disequilibrium mapping was conducted for the identification of epiQTLs in plants [99]. Using $550 \mathrm{~F}_{1} \mathrm{~s}$ and 435 natural germplasm accessions, manyepiQTLs (163 epiQTLs) were found to be associated with growth and wood properties in Populus. Furthermore, 23 causal genes present within epiQTL regions showed cause and effect relationship as revealed by the coregulation of eQTN (expression quantitative trait nucleotide) and eQTM (expression quantitative trait methylation) [99].

Identification of epiQTLs by using any of the methods mentioned above, high-density epi-genotyping is a significant challenge. However, with the advancement in sequencing technologies, high-density epi-genotyping is now possible. Different techniques like epigenetic based restriction-site associated DNA sequencing (epiRADseq), bisulfite-converted restriction site-associated DNA sequencing (bsRADseq), epi-genotyping by sequencing (epi-GBS) [100-102] are available for high-density epi-genotyping. Each of these methods has its advantages and limitations. For instance, epiRADseq is as cheap as compared to bsRADseq; however, it utilizes HpalI methylation-sensitive restriction enzyme, thus it is restricted to only limited sites. The bsRADseq covers all the context of cytosine methylations, but it requires a reference genome for downstream analysis, therefore it is not suitable for non-reference based organisms. Epi-GBS is a cost-effective and less time-consuming approach. Although the cost of epi-GBS can further be reduced by using single hemi-methylated adapters [103]. Moreover, Epi-GBS can also be applied to plants where a reference genome is not available. A successful example of utilization epi-GBS for identification of DMRs is available in the case of almond where epi-GBS identified more than 7000 methylated fragments and among these 677 fragments were differentially methylated. Furthermore, the methylation state of some gene-coding sequences was found to be associated with flower bud dormancy [104]. 
As mentioned earlier, several epialleles have been reported in plants, and huge opportunities still exist to explore it further in various plant species. Thus, we strongly recommend that EWAS should be performed in crop plants, which will contribute to improving our understanding of epigenetic mechanisms regulating phenotypic traits, and also expedite crop improvement programs through epibreeding.

\section{Epigenome Editing Using Site-Specific Nucleases}

Several tools are reported that allow site-specific manipulation of DNA methylation/demethylation using programmable DNA-binding proteins [zinc finger ( $\mathrm{ZFs}$ ) proteins and CRISPR-dCas9] in plants [105]. In Arabidopsis, it was shown that ZF fused with RdDM component SU(VAR)3-9 HOMOLOG 9 (SUVH9) was able to cause target methylation to the FWA promoter. It caused FWA silencing via heritable methylation and led to the late-flowering phenotype [106]. Recently, Gallego-Bartolome et al. [107] tested the capability of several other RdDM components (i.e., RNA-dependent RNA polymerase 2 (RDR2), Sawadee Homeodomain Homolog 1 (SHH1), Microrchidia 1 (MORC1), MORC6, Defective in Meristem Silencing 3 (DMS3), and RNA-Directed DNA Methylation 1 (RDM1)) to promote targeted DNA methylation at FWA locus when fused with ZF. This study provides a theoretical framework that can be utilized to design efficient targeted DNA-methylation programs in plants. In addition to ZF nucleases, CRISPR-dCas9 was also used to target DNA methylation in plants [108]. Recently developed CRISPR-Cas9-SunTag system having the catalytic domain of tobacco DRM has been used to target a FWA locus that showed heritable DNA methylation in Arabidopsis [108]. Besides DNA methylation, targeted DNA demethylation has also been performed by fusing Ten-Eleven Translocation 1 (TET1) to both ZF and CRISPR-Cas9-SunTag systems in Arabidopsis [109]. The DNA demethylation achieved at the FWA promoter was found highly specific and heritable in nature. Further development of these tools for targeted DNA methylation and demethylation in plants other than Arabidopsis will open up new avenues to study locus-specific effects of DNA methylation and could be used for the generation of new epialleles.

Epigenome editing techniques utilizing CRISPR system have significant potential for crop improvement. However, in a recent international survey it has been found that consumers equate CRISPR/Cas to traditional genetically modified organisms (GMO) [110]. Notably, CRISPR technique introduce changes to DNA intrinsic to the target species, while traditional genetic modification introduces foreign DNA from a different species (i.e., transgenic) or another cultivar of the same species (i.e., cisgenic) [111]. Importantly, DNA-free delivery of CRISPR-Cas9 ribonucleoproteins might be considered non-GM crops. This would open the door for the development and commercialization of superior crops in various countries even where GM crops are unacceptable.

\section{Conclusions and Future Prospects}

Strengthening crop improvement programs is crucial to feed the global population. Utilization of epigenetic information at the epiQTLs and epialleles level may provide new prospects for crop improvement as existing breeding methods primarily focus on genetic and ignore epigenetic aspects. The advancement of new sequencing technologies like BS-seq (bisulphite sequencing) and MethylC-seq (methylC-sequencing) can help to delineate the epigenetic basis of trait determination. This information will eventually enhance the inclusion of epigenetic methods in crop improvement. Furthermore, loci-specific DNA methylation patterns can be achieved in plant genomes by fusion of catalytic domains of de novo DNA methylation or demethylation enzymes with nucleases (i.e., zinc finger nucleases (ZFNs), and clustered regularly interspaced short palindromic repeats/dCRISPR-associated protein 9 (CRISPR-dCas9 systems)). These systems have been employed to engineer epigenomes of mammalian cell lines $[112,113]$ and plants $[108,109]$. Epigenome engineering will not only help in the functional validation of DNA methylation patterns regulating phenotypic traits but will also help to generate desirable traits by creating epigenomic diversity and can accelerate crop improvement by epibreeding [106]. 
Author Contributions: Conceptualization: V.G. and V.J.; Bibliographic/literature search, V.G. and V.J.; Writing-original draft preparation, V.G., G.Z. and V.J. Writing-review and editing: V.G., G.Z., V.J. and S.K.; Supervision, S.K. All authors have read and agreed to the published version of the manuscript.

Funding: This research was funded by Council of Scientific and Industrial Research, India grant number MLP-201 and Department of Science and technology for the INSPIRE faculty award (DST/INSPIRE/04/2017/000413).

Acknowledgments: Thanks are due to the Council of Scientific and Industrial Research for providing funds, V.J. and V.G. thanks to the Department of Science and technology for the INSPIRE faculty award. V.J. also thanks to the Science and Engineering Research Board for the Early Career Research Award. This manuscript represents CSIR-IHBT communication number: 4718.

Conflicts of Interest: The authors declare no conflict of interest.

\section{References}

1. Feng, S.; Jacobsen, S.E.; Reik, W. Epigenetic reprogramming in plant and animal development. Science 2010, 330, 622-627. [CrossRef]

2. Simon, S.A.; Meyers, B.C. Small RNA-mediated epigenetic modifications in plants. Curr. Opin. Plant Biol. 2011, 14, 148-155. [CrossRef] [PubMed]

3. Law, J.A.; Ausin, I.; Johnson, L.M.; Vashisht, A.A.; Zhu, J.K.; Wohlschlegel, J.A.; Jacobsen, S.E. A protein complex required for polymerase $\mathrm{V}$ transcripts and RNA- directed DNA methylation in Arabidopsis. Curr. Biol. 2010, 20, 951-956. [CrossRef] [PubMed]

4. Niederhuth, C.E.; Bewick, A.J.; Ji, L.; Alabady, M.S.; Kim, K.D.; Li, Q.; Rohr, N.A.; Rambani, A.; Burke, J.M.; Udall, J.A.; et al. Widespread natural variation of DNA methylation within angiosperms. Genome Biol. 2016, 17, 194. [CrossRef] [PubMed]

5. Law, J.A.; Jacobsen, S.E. Establishing, maintaining and modifying DNA methylation patterns in plants and animals. Nat. Rev. Genet. 2010, 11, 204-220. [CrossRef]

6. Cao, X.; Aufsatz, W.; Zilberman, D.; Mette, M.F.; Huang, M.S.; Matzke, M.; Jacobsen, S.E. Role of the DRM and CMT3 methyltransferases in RNA-directed DNA methylation. Curr. Biol. 2003, 13, 2212-2217. [CrossRef] [PubMed]

7. Gent, J.I.; Ellis, N.A.; Guo, L.; Harkess, A.E.; Yao, Y.; Zhang, X.; Dawe, R.K. CHH islands: De novo DNA methylation in near-gene chromatin regulation in maize. Genome Res. 2013, 23, 628-637. [CrossRef]

8. Saze, H.; Mittelsten Scheid, O.; Paszkowski, J. Maintenance of CpG methylation is essential for epigenetic inheritance during plant gametogenesis. Nat. Genet. 2003, 34, 65-69. [CrossRef]

9. Zemach, A.; Kim, M.Y.; Hsieh, P.H.; Coleman-Derr, D.; Eshed-Williams, L.; Thao, K.; Harmer, S.L.; Zilberman, D. The Arabidopsis nucleosome remodeler DDM1 allows DNA methyltransferases to access H1-containing heterochromatin. Cell 2013, 153, 193-205. [CrossRef]

10. Stroud, H.; Do, T.; Du, J.; Zhong, X.; Feng, S.; Johnson, L.; Patel, D.J.; Jacobsen, S.E. Non-CG methylation patterns shape the epigenetic landscape in Arabidopsis. Nat. Struct. Mol. Biol. 2014, 21, 64-72. [CrossRef]

11. Zhang, H.; Lang, Z.; Zhu, J. Dynamics and function of DNA methylation in plants. Nat. Rev. Mol. Cell Biol. 2018, 19, 489-506. [CrossRef] [PubMed]

12. Yong, W.; Hsu, F.; Chen, P. Profiling genome-wide DNA methylation. Epigenetics Chromatin 2016, 9, 26. [CrossRef]

13. Kawakatsu, T.; Huang, S.C.; Jupe, F.; Sasaki, E.; Schmitz, R.J.; Urich, M.A.; Castanon, R.; Nery, J.R.; Barragan, C.; He, Y.; et al. Epigenomic Diversity in a Global Collection of Arabidopsis thaliana Accessions. Cell 2016, 166, 492-505. [CrossRef]

14. Laird, P.W. Principles and challenges of genomewide DNA methylation analysis. Nat. Rev. Genet. 2010, 11, 191-203. [CrossRef] [PubMed]

15. Cokus, S.J.; Feng, S.; Zhang, X.; Chen, Z.; Merriman, B.; Haudenschild, C.D.; Pradhan, S.; Nelson, S.F.; Pellegrini, M.; Jacobsen, S.E. Shotgun bisulphite sequencing of the Arabidopsis genome reveals DNA methylation patterning. Nature 2008, 452, 215-219. [CrossRef]

16. Li, Q.; Eichten, S.R.; Hermanson, P.J.; Springer, N.M. Inheritance patterns and stability of DNA methylation variation in maize near-isogenic lines. Genetics 2014, 196, 667-676. [CrossRef]

17. Gardiner, L.J.; Quinton-Tulloch, M.; Olohan, L.; Price, J.; Hall, N.; Hall, A. A genome-wide survey of DNA methylation in hexaploid wheat. Genome Biol. 2015, 16, 273. [CrossRef] 
18. Lister, R.; O’Malley, R.C.; Tonti-Filippini, J.; Gregory, B.D.; Berry, C.C.; Millar, A.H.; Ecker, J.R. Highly integrated single-base resolution maps of the epigenome in Arabidopsis. Cell 2008, 133, 523-536. [CrossRef]

19. Sinha, P.; Singh, V.K.; Saxena, R.K.; Kale, S.M.; Li, Y.; Garg, V.; Meifang, T.; Khan, A.W.; Kim, K.D.; Chitikineni, A.; et al. Genome-wide analysis of epigenetic and transcriptional changes associated with heterosis in pigeonpea. Plant Biotechnol. J. 2020, 18, 1697-1710. [CrossRef]

20. Wang, L.; Shi, Y.; Chang, X.; Jing, S.; Zhang, Q.; You, C.; Yuan, H.; Wang, H. DNA methylome analysis provides evidence that the expansion of the tea genome is linked to TE bursts. Plant Biotechnol. J. 2019, 17, 826-835. [CrossRef]

21. Bhatia, H.; Khemka, N.; Jain, M.; Garg, R. Genome-wide bisulphite-sequencing reveals organ-specific methylation patterns in chickpea. Sci. Rep. 2018, 8, 9704. [CrossRef] [PubMed]

22. An, Y.C.; Goettel, W.; Han, Q.; Bartels, A.; Liu, Z.; Xiao, W. Dynamic Changes of Genome-Wide DNA Methylation during Soybean Seed Development. Sci. Rep. 2017, 7, 12263. [CrossRef]

23. Wang, L.; Xie, J.; Hu, J.; Lan, B.; You, C.; Li, F.; Wang, Z.; Wang, H. Comparative epigenomics reveals evolution of duplicated genes in potato and tomato. Plant J. 2018, 93, 460-471. [CrossRef]

24. Hauser, M.T.; Aufsatz, W.; Jonak, C.; Luschnig, C. Transgenerational epigenetic inheritance in plants. Biochim. Biophys. Acta 2011, 1809, 459-468. [CrossRef]

25. Zemach, A.; Zilberman, D. Evolution of eukaryotic DNA methylation and the pursuit of safer sex. Curr. Biol. 2010, 20, R780-R785. [CrossRef] [PubMed]

26. Hofmeister, B.T.; Lee, K.; Rohr, N.A.; Hall, D.W.; Schmitz, R.J. Stable inheritance of DNA methylation allows creation of epigenotype maps and the study of epiallele inheritance patterns in the absence of genetic variation. Genome Biol. 2017, 18, 155. [CrossRef]

27. Wang, G.; Köhler, C. Epigenetic processes in flowering plant reproduction. J. Exp. Bot. 2017, 68, 797-807. [CrossRef]

28. Chow, H.T.; Chakraborty, T.; Mosher, R.A. RNA-directed DNA Methylation and sexual reproduction: Expanding beyond the seed. Curr. Opin. Plant Biol. 2020, 54, 11-17. [CrossRef]

29. Jacobsen, S.E.; Meyerowitz, E.M. Hypermethylated superman epigenetic alleles in Arabidopsis. Science 1997, 277, 1100-1103. [CrossRef]

30. Soppe, W.J.J.; Jacobsen, S.E.; Alonso-Blanco, C.; Jackson, J.P.; Kakutani, T.; Koornneef, M.; Peeters, A.J.M. The late flowering phenotype of fwa mutants is caused by gain-of-function epigenetic alleles of a homeodomain gene. Mol. Cell 2000, 6, 791-802. [CrossRef]

31. Stokes, T.L.; Kunkel, B.N.; Richards, E.J. Epigenetic variation in Arabidopsis disease resistance. Genes Dev. 2002, 16, 171-182. [CrossRef]

32. Cocciolone, S.M.; Chopra, S.; Flint-Garcia, S.A.; McMullen, M.D.; Peterson, T. Tissue-specific patterns of a maize Myb transcription factor are epigenetically regulated. Plant J. 2001, 27, 467-478. [CrossRef]

33. He, L.; Wu, W.; Zinta, G.; Yang, L.; Wang, D.; Liu, R.; Zhang, H.; Zheng, Z.; Huang, H.; Zhang, Q.; et al. A naturally occurring epiallele associates with leaf senescence and local climate adaptation in Arabidopsis accessions. Nat. Commun. 2018, 9, 460. [CrossRef] [PubMed]

34. Johannes, F.; Porcher, E.; Teixeira, F.K.; Saliba-Colombani, V.; Simon, M.; Agier, N.; Bulski, A.; Albuisson, J.; Heredia, F.; Audigier, P.; et al. Assessing the impact of transgenerational epigenetic variation on complex traits. PLoS Genet. 2009, 5, e1000530. [CrossRef]

35. Cortijo, S.; Wardenaar, R.; Colome-Tatche, M.; Gilly, A.; Etcheverry, M.; Labadie, K.; Caillieux, E.; Hospital, F.; Aury, J.M.; Wincker, P.; et al. Mapping the epigenetic basis of complex traits. Science 2014, 343, 1145-1148. [CrossRef]

36. Slatkin, M. Epigenetic inheritance and the missing heritability problem. Genetics 2009, 182, 845-850. [CrossRef]

37. Becker, C.; Weigel, D. Epigenetic variation: Origin and transgenerational inheritance. Curr. Opin. Plant Biol. 2012, 15, 562-567. [CrossRef] [PubMed]

38. Cubas, P.; Vincent, C.; Coen, E. An epigenetic mutation responsible for natural variation in floral symmetry. Nature 1999, 401, 157-161. [CrossRef]

39. Manning, K.; Tor, M.; Poole, M.; Hong, Y.; Thompson, A.J.; King, G.J.; Giovannoni, J.J.; Seymour, G.B. A naturally occurring epigenetic mutation in a gene encoding an sbp-box transcription factor inhibits tomato fruit ripening. Nat. Genet. 2006, 38, 948-952. [CrossRef] 
40. Quadrana, L.; Almeida, J.; Asís, R.; Duffy, T.; Dominguez, P.G.; Bermúdez, L.; Conti, G.; Corrêa da Silva, J.V.; Peralta, I.E.; Colot, V.; et al. Natural occurring epialleles determine vitamin E accumulation in tomato fruits. Nat. Commun. 2014, 5, 3027. [CrossRef]

41. Martin, A.; Troadec, C.; Boualem, A.; Rajab, M.; Fernandez, R.; Morin, H.; Pitrat, M.; Dogimont, C.; Bendahmane, A. A transposon-induced epigenetic change leads to sex determination in melon. Nature 2009, 461, 1135-1138. [CrossRef] [PubMed]

42. Shiba, H.; Kakizaki, T.; Iwano, M.; Tarutani, Y.; Watanabe, M.; Isogai, A.; Takayama, S. Dominance relationships between self-incompatibility alleles controlled by DNA methylation. Nat. Genet. 2006, 38, 297-299. [CrossRef]

43. Bender, J.; Fink, G.R. Epigenetic control of an endogenous gene family is revealed by a novel blue fluorescent mutant of Arabidopsis. Cell 1995, 83, 725-734. [CrossRef]

44. Jacobsen, S.E.; Sakai, H.; Finnegan, E.J.; Cao, X.; Meyerowitz, E.M. Ectopic hypermethylation of flower specific genes in Arabidopsis. Curr. Biol. 2000, 24, 179-186. [CrossRef]

45. Saze, H.; Shiraishi, A.; Miura, A.; Kakutani, T. Control of genic DNA methylation by a jmjc domain-containing protein in Arabidopsis thaliana. Science 2008, 319, 462-465. [CrossRef]

46. Durand, S.; Bouche, N.; Perez, S.E.; Loudet, O.; Camilleri, C. Rapid establishment of genetic incompatibility through natural epigenetic variation. Curr. Biol. 2012, 22, 326-331. [CrossRef]

47. Silveira, A.B.; Trontin, C.; Cortijo, S.; Barau, J.; Del Bem, L.E.; Loudet, O.; Colot, V.; Vincentz, M. Extensive natural epigenetic variation at a de novo originated gene. PLoS Genet. 2013, 9, e1003437. [CrossRef] [PubMed]

48. Blevins, T.; Wang, J.; Pflieger, D.; Pontvianne, F.; Pikaard, C.S. Hybrid incompatibility caused by an epiallele. Proc. Natl. Acad. Sci. USA 2017, 114, 3702-3707. [CrossRef]

49. Brink, R.A. A Genetic Change Associated with the $R$ Locus in Maize Which Is Directed and Potentially Reversible. Genetics 1956, 41, 872-889.

50. Patterson, G.I.; Thorpe, C.J.; Chandler, V.L. Paramutation, an allelic interaction, is associated with a stable and heritable reduction of transcription of the maize b regulatory gene. Genetics 1993, 135, 881-894.

51. Hollick, J.B.; Patterson, G.I.; Coe, E.H.; Cone, K.C.; Chandler, V.L. Allelic interactions heritably influence the activity of a metastable maize pl allele. Genetics 1995, 141, 709-719. [PubMed]

52. Pilu, R.; Panzeri, D.; Cassani, E.; Cerino Badone, F.; Landoni, M.; Nielsen, E.A. paramutation phenomenon is involved in the genetics of maize low phytic acid1-241 (lpa1-241) trait. Heredity 2009, 102, 236-245. [CrossRef]

53. Miura, K.; Agetsuma, M.; Kitano, H.; Yoshimura, A.; Matsuoka, M.; Jacobsen, S.E.; Ashikari, M. A metastable dwarf1 epigenetic mutant affecting plant stature in rice. Proc. Natl. Acad. Sci. USA 2009, 106, 11218-11223. [CrossRef]

54. Miura, K.; Ikeda, M.; Matsubara, A.; Song, X.J.; Ito, M.; Asano, K.; Matsuoka, M.; Kitano, H.; Ashikari, M. Osspl14 promotes panicle branching and higher grain productivity in rice. Nat. Genet. 2010, 42, 545-549. [CrossRef]

55. Zhang, L.; Cheng, Z.; Qin, R.; Qiu, Y.; Wang, J.L.; Cui, X.; Gu, L.; Zhang, X.; Guo, X.; Wang, D.; et al. Identification and characterization of an epi-allele of fie1 reveals a regulatory linkage between two epigenetic marks in rice. Plant Cell 2012, 24, 4407-4421. [CrossRef]

56. Zhang, X.; Sun, J.; Cao, X.; Song, X. Epigenetic Mutation of RAV6 Affects Leaf Angle and Seed Size in Rice. Plant Physiol. 2015, 169, 2118-2128.

57. Wei, X.; Song, X.; Wei, L.; Tang, S.; Sun, J.; Hu, P.; Cao, X. An epiallele of rice AK1 affects photosynthetic capacity. J. Integr. Plant Biol. 2017, 59, 158-163. [CrossRef] [PubMed]

58. Luan, X.; Liu, S.; Ke, S.; Dai, H.; Xie, X.M.; Hsieh, T.F.; Zhang, X.Q. Epigenetic modification of ESP, encoding a putative long noncoding RNA, affects panicle architecture in rice. Rice 2019, 12, 20. [CrossRef]

59. Ong-Abdullah, M.; Ordway, J.M.; Jiang, N.; Ooi, S.E.; Kok, S.Y.; Sarpan, N.; Azimi, N.; Hashim, A.T.; Ishak, Z.; Rosli, S.K.; et al. Loss of Karma transposon methylation underlies the mantled somaclonal variant of oil palm. Nature 2015, 525, 533-537. [CrossRef] [PubMed]

60. Zhang, Y.; Wendte, J.M.; Ji, L.; Schmitz, R.J. Natural variation in DNA methylation homeostasis and the emergence of epialleles. Proc. Natl. Acad. Sci. USA 2020, 117, 4874-4884. [CrossRef]

61. Mirouze, M.; Paszkowski, J. Epigenetic contribution to stress adaptation in plants. Curr. Opin. Plant Biol. 2011, 14, 267-274. [CrossRef]

62. Kooke, R.; Keurentjes, J.J.B. Epigenetic variation contributes to environmental adaptation of Arabidopsis thaliana. Plant Signal. Behav. 2015, 10, e1057368. [CrossRef] 
63. Reinders, J.; Wulff, B.B.; Mirouze, M.; Marí-Ordonez, A.; Dapp, M.; Rozhon, W.; Bucher, E.; Theiler, G.; Paszkowski, J. Compromised stability of DNA methylation and transposon immobilization in mosaic Arabidopsis epigenomes. Genes Dev. 2009, 23, 939-950. [CrossRef]

64. Kankel, M.W.; Ramsey, D.E.; Stokes, T.L.; Flowers, S.K.; Haag, J.R.; Jeddeloh, J.A.; Riddle, N.C.; Verbsky, M.L.; Richards, E.J. Arabidopsis MET1 cytosine methyltransferase mutants. Genetics 2003, 163, 1109-1122.

65. Jeddeloh, J.A.; Stokes, T.L.; Richards, E.J. Maintenance of genomic methylation requires a SWI2/SNF2-like protein. Nat Genet. 1999, 22, 94-97. [CrossRef]

66. Lippman, Z.; Gendrel, A.V.; Black, M.; Vaughn, M.W.; Dedhia, N.; McCombie, W.R.; Lavine, K.; Mittal, V.; May, B.; Kasschau, K.D.; et al. Role of transposable elements in heterochromatin and epigenetic control. Nature 2004, 430, 471-476. [CrossRef]

67. Vongs, A.; Kakutani, T.; Martienssen, R.A.; Richards, E.J. Arabidopsis thaliana DNA methylation mutants. Science 1993, 260, 1926-1928. [CrossRef]

68. Kakutani, T.; Munakata, K.; Richards, E.J.; Hirochika, H. Meiotically and mitotically stable inheritance of DNA hypomethylation induced by ddm1 mutation of Arabidopsis thaliana. Genetics 1999, 151, 831-838.

69. Teixeira, F.K.; Heredia, F.; Sarazin, A.; Roudier, F.; Boccara, M.; Ciaudo, C.; Cruaud, C.; Poulain, J.; Berdasco, M.; Fraga, M.F.; et al. A role for RNAi in the selective correction of DNA methylation defects. Science 2009, 323, 1600-1604. [CrossRef] [PubMed]

70. Li, J.; Yang, D.L.; Huang, H.; Zhang, G.; He, L.; Pang, J.; Lozano-Durán, R.; Lang, Z.; Zhu, J.K. Epigenetic memory marks determine epiallele stability at loci targeted by de novo DNA methylation. Nat. Plants 2020, 6, 661-674. [CrossRef]

71. McKeown, P.C.; Fort, A.; Duszynska, D.; Sulpice, R.; Spillane, C. Emerging molecular mechanisms for biotechnological harnessing of heterosis in crops. Trends Biotechnol. 2013, 31, 549-551. [CrossRef] [PubMed]

72. Chen, Z.J. Genomic and epigenetic insights into the molecular bases of heterosis. Nat. Rev. Genet. 2013, 14, 471-482. [CrossRef]

73. Groszmann, M.; Greaves, I.K.; Fujimoto, R.; Peacock, W.J.; Dennis, E.S. The role of epigenetics in hybrid vigour. Trends Genet. 2013, 29, 684-690. [CrossRef]

74. Lauss, K.; Wardenaar, R.; Oka, R.; van Hulten, M.; Guryev, V.; Keurentjes, J.; Stam, M.; Johannes, F. Parental DNA Methylation States are associated with Heterosis in Epigenetic Hybrids. Plant Physiol. 2018, 176, 1627-1645. [CrossRef]

75. Shen, H.; He, H.; Li, J.; Chen, W.; Wang, X.; Guo, L.; Peng, Z.; He, G.; Zhong, S.; Qi, Y.; et al. Genome-wide analysis of DNA methylation and gene expression changes in two Arabidopsis ecotypes and their reciprocal hybrids. Plant Cell 2012, 24, 875-892. [CrossRef]

76. Zhang, Q.; Wang, D.; Lang, Z.; He, L.; Yang, L.; Zeng, L.; Li, Y.; Zhao, C. Methylation interactions in Arabidopsis hybrids require RNA-directed DNA methylation and are influenced by genetic variation. Proc. Natl. Acad. Sci. USA 2016, 113, E4248-E4256. [CrossRef]

77. Groszmann, M.; Greaves, I.K.; Albertyn, Z.I.; Scofield, G.N.; Peacock, W.J.; Dennis, E.S. Changes in 24-nt siRNA levels in Arabidopsis hybrids suggest an epigenetic contribution to hybrid vigor. Proc. Natl. Acad. Sci. USA 2011, 108, 2617-2622. [CrossRef]

78. Zhang, H.; Wang, B.; Duan, C.G.; Zhu, J.K. Chemical probes in plant epigenetics studies. Plant Signal Behav. 2013, 8, e25364. [CrossRef]

79. Amoah, S.; Kurup, S.; Lopez, C.M.R.; Welham, S.J.; Powers, S.J.; Hopkins, C.J.; Wilkinson, M.J.; King, G.J. A Hypomethylated population of Brassica rapa for forward and reverse Epi-genetics. BMC Plant Biol. 2012, 12, 193. [CrossRef]

80. Tal, O.; Kisdi, E.; Jablonka, E. Epigenetic contribution to covariance between relatives. Genetics 2010, 184, 1037-1050. [CrossRef] [PubMed]

81. Johannes, F.; Colome-Tatche, M. Quantitative epigenetics through epigenomic perturbation of isogenic lines. Genetics 2011, 188, 215-227. [CrossRef]

82. Furrow, R.E.; Christiansen, F.B.; Feldman, M.W. Environment-sensitive epigenetics and the heritability of complex diseases. Genetics 2011, 189, 1377-1387. [CrossRef] [PubMed]

83. O'Sullivan, E.; Goggins, M. DNA methylation analysis in human cancer. Methods Mol. Biol. 2013, 980, 131-156. 
84. Estival, A.; Sanz, C.; Ramirez, J.L.; Velarde, J.M.; Domenech, M.; Carrato, C.; de Las Peñas, R.; Gil-Gil, M.; Sepúlveda, J.; Armengol, R.; et al. Pyrosequencing versus methylation-specific PCR for assessment of MGMT methylation in tumor and blood samples of glioblastoma patients. Sci. Rep. 2019, 9, 11125. [CrossRef]

85. Munson, K.; Clark, J.; Lamparska-Kupsik, K.; Smith, S.S. Recovery of bisulfite-converted genomic sequences in the methylation-sensitive QPCR. Nucleic Acids Res. 2007, 35, 2893-2903. [CrossRef]

86. Hernández, H.G.; Tse, M.Y.; Pang, S.C.; Arboleda, H.; Forero, D.A. Optimizing methodologies for PCR-based DNA methylationn analysis. Biotechniques 2013, 55, 181-197. [CrossRef] [PubMed]

87. Kanherkar, R.R.; Bhatia-Dey, N.; Csoka, A.B. Epigenetics across the human lifespan. Front. Cell Dev. Biol. 2014, 2, 49. [CrossRef]

88. Jaffe, A.E.; Feinberg, A.P.; Irizarry, R.A.; Leek, J.T. Significance analysis and statistical dissection of variably methylated regions. Biostatistics 2012, 13, 166-178. [CrossRef]

89. Roux, F.; Colome-Tatche, M.; Edelist, C.; Warenaar, R.; Guerche, P.; Hospital, F.; Colot, V.; Jansen, R.C.; Johannes, F. Genome-wide epigenetic perturbation jump-starts patterns of heritable variation found in nature. Genetics 2011, 188, 1015-1017. [CrossRef]

90. Wang, Z.; Wang, Z.; Wang, J.; Sui, Y.; Zhang, J.; Liao, D.; Wu, R. A quantitative genetic and epigenetic model of complex traits. BMC Bioinform. 2012, 13, 274. [CrossRef] [PubMed]

91. Long, Y.; Xia, W.; Li, R.; Wang, J.; Shao, M.; Feng, J.; King, G.J.; Meng, J. Epigenetic QTL mapping in Brassica napus. Genetics 2011, 189, 1093-1102. [CrossRef] [PubMed]

92. Duan, Y.; Qian, J.; Sun, Y.; Yi, Z.; Yan, M. Construction of methylation linkage map based on MSAP and SSR markers in Sorghum bicolor (L.). IUBMB Life 2009, 61, 663-669. [CrossRef]

93. Schmitz, R.J.; He, Y.; Lopez, O.V.; Khan, S.M.; Joshi, T.; Urich, M.A.; Nery, J.R.; Diers, B.; Xu, D.; Stacey, G.; et al. Epigenome-wide inheritance of cytosine methylation variants in a recombinant inbred population. Genome Res. 2013, 23, 1663-1674. [CrossRef]

94. Moore, K.; McKnight, A.J.; Craig, D.; O’Neill, F. Epigenome-Wide Association Study for Parkinson's Disease. Neuro Mol. Med. 2014, 16, 845-855. [CrossRef]

95. Sharma, P.; Garg, G.; Kumar, A.; Mohammad, F.; Kumar, S.R.; Tanwar, V.S.; Sati, S.; Sharma, A.; Karthikeyan, G.; Brahmachari, V.; et al. Genome wide DNA methylation profiling for epigenetic alteration in coronary artery disease patients. Gene 2014, 541, 31-40. [CrossRef] [PubMed]

96. Gasparoni, G.; Bultmann, S.; Lutsik, P.; Kraus, T.; Sordon, S.; Vlcek, J.; Dietinger, V.; Steinmaurer, M.; Haider, M.; Mulholland, C.B.; et al. DNA methylation analysis on purified neurons and glia dissects age and Alzheimer's disease-specific changes in the human cortex. Epigenetics Chromatin 2018, 11, 41. [CrossRef]

97. Cardona, A.; Day, F.R.; Perry, J.; Loh, M.; Chu, A.Y.; Lehne, B.; Paul, D.S.; Lotta, L.A.; Stewart, I.D.; Kerrison, N.D.; et al. Epigenome-Wide Association Study of Incident Type 2 Diabetes in a British Population: EPIC-Norfolk Study. Diabetes 2019, 68, 2315-2326. [CrossRef]

98. Li, M.; Zou, D.; Li, Z.; Gao, R.; Sang, J.; Zhang, Y.; Li, R.; Xia, L.; Zhang, T.; Niu, G.; et al. EWAS Atlas: A curated knowledgebase of epigenome-wide association studies. Nucleic Acids Res. 2019, 47, D983-D988. [CrossRef]

99. Lu, W.; Xiao, L.; Quan, M.; Wang, Q.; El-Kassaby, Y.A.; Du, Q.; Zhang, D. Linkage-linkage disequilibrium dissection of the epigenetic quantitative trait loci (epiQTLs) underlying growth and wood properties in Populus. New Phytol. 2020, 225, 1218-1233. [CrossRef]

100. Schield, D.R.; Walsh, M.R.; Card, D.C.; Andrew, A.L.; Adams, R.H.; Castoe, T.A. EpiRADseq: Scalable analysis of genomewide patterns of methylation using next-generation sequencing. Methods Ecol. Evol. 2016, 7, 60-69. [CrossRef]

101. Trucchi, E.; Mazzarella, A.B.; Gilfillan, G.D.; Lorenzo, M.T.; Schönswetter, P.; Paun, O. BsRADseq: Screening DNA methylation in natural populations of non-model species. Mol. Ecol. 2016, 25, 1697-1713. [CrossRef]

102. van Gurp, T.P.; Wagemaker, N.C.; Wouters, B.; Vergeer, P.; Ouborg, J.N.; Verhoeven, K.J. epiGBS: Reference-free reduced representation bisulfite sequencing. Nat. Methods 2016, 13, 322-324. [CrossRef]

103. Werner, O.; Prudencio, Á.S.; de la Cruz-Martínez, E.; Nieto-Lugilde, M.; Martínez-Gómez, P.; Ros, R.M. A Cost Reduced Variant of Epi-Genotyping by Sequencing for Studying DNA Methylation in Non-model Organisms. Front. Plant Sci. 2020, 11, 694. [CrossRef]

104. Prudencio, Á.S.; Werner, O.; Martínez-García, P.J.; Dicenta, F.; Ros, R.M.; Martínez-Gómez, P. DNA Methylation Analysis of Dormancy Release in Almond (Prunus dulcis) Flower Buds Using Epi-Genotyping by Sequencing. Int. J. Mol. Sci. 2018, 19, 3542. [CrossRef] 
105. Gallego-Bartolomé, J. DNA methylation in plants: Mechanisms and tools for targeted manipulation. New Phytol. 2020, 227, 38-44. [CrossRef] [PubMed]

106. Johnson, L.M.; Du, J.; Hale, C.J.; Bischof, S.; Feng, S.; Chodavarapu, R.K.; Zhong, X.; Marson, G.; Pellegrini, M.; Segal, D.J.; et al. SRA- and SET-domain-containing proteins link RNA polymerase V occupancy to DNA methylation. Nature 2014, 507, 124-128. [CrossRef]

107. Gallego-Bartolomé, J.; Liu, W.; Kuo, P.H.; Feng, S.; Ghoshal, B.; Gardiner, J.; Zhao, J.M.; Park, S.Y.; Chory, J.; Jacobsen, S.E. Co-targeting RNA Polymerases IV and V Promotes Efficient De Novo DNA Methylation in Arabidopsis. Cell 2019, 176, 1068-1082. [CrossRef] [PubMed]

108. Papikian, A.; Liu, W.; Gallego-Bartolomé, J.; Jacobsen, S.E. Site-specific manipulation of Arabidopsis loci using CRISPR-Cas9 SunTag systems. Nat. Commun. 2019, 10, 729. [CrossRef]

109. Gallego-Bartolomé, J.; Gardiner, J.; Liu, W.; Papikian, A.; Ghoshal, B.; Kuo, H.Y.; Zhao, J.M.; Segal, D.J.; Jacobsen, S.E. Targeted DNA demethylation of the Arabidopsis genome using the human TET1 catalytic domain. Proc. Natl. Acad. Sci. USA 2018, 115, E2125-E2134. [CrossRef]

110. Shew, A.M.; Nallwy, L.L.; Snell, H.A.; Nayga, R.M.; Dixon, B.L. CRISPR Versus GMOs: Public Acceptance and Valuation. Glob. Food Secur. 2018, 19, 71-80. [CrossRef]

111. Ishii, T.; Araki, M. Consumer acceptance of food crops developed by genome editing. Plant Cell Rep. 2016, 35, 1507-1518. [CrossRef]

112. Amabile, A.; Migliara, A.; Capasso, P.; Biffi, M.; Cittaro, D.; Naldini, L.; Lombardo, A. Inheritable Silencing of Endogenous Genes by Hit-and-Run Targeted Epigenetic Editing. Cell 2016, 167, 219-232.e14. [CrossRef]

113. Liu, X.S.; Wu, H.; Ji, X.; Stelzer, Y.; Wu, X.; Czauderna, S.; Shu, J.; Dadon, D.; Young, R.A.; Jaenisch, R. Editing DNA Methylation in the Mammalian Genome. Cell 2016, 167, 233-247.e17. [CrossRef]

Publisher's Note: MDPI stays neutral with regard to jurisdictional claims in published maps and institutional affiliations. 